Небојша М. Раденковић

Правно пословна школа

Ниш

nebojsaradenkovic@yahoo.com
Оригиналан научни рад

примљено: 3. јун 2014

прихваћено: 1. октобар 2014

\title{
ТРАГОВИ АНТИЧКОГ НИША У ДЕЛИМА ПУТОПИСАЦА ХVI ВЕКА
}

Сажетак: Територија каснијег античког Наисуса (Naissus) била је интересантно подручје још у праисторији, али ће се тек са доласком Римљана овде формирати насеље већег обима које ће временом прерасти у врло значајан град. Његовим ширењем и изградњом овде настају војни логор, градско утврђење, водовод, занатске радионице, царска резиденција, некрополе.

Наисус представља и врло важну раскрсницу путева који из овог града иду у свим правцима: према југу - правац Улпијана-Лисус, односно Скупи; према северу Виминацијум-Сингидунум; према североистоку - Тимакум-Ратијарија; према истоку Сердика-Константинополис. Као такав он је био врло значајна локација за Римљане који су га, несумњиво због тога, увелико и изграђивали и бранили. Наисус је познат и као царски град, јер се у њему родио и једно време живео цар Константин о чијим се делатностима, како у градитељском тако и политичком развоју Римске империје, много може говорити. Његови наследници ће врло успешно наставити да раде на урбанизацији и изградњи Наисуса а многи остаци тога сачувани су до данас. У овом раду аутор говори о неколицини путописаца из западних земаља који су у XVI веку путовали према седишту турске царевине, Цариграду, и који су оставили значајне податке о античким остацима и локалитетима Наисуса. Многи од ових података били су веома драгоцени каснијим истраживачима ових локалитета иако неки од описаних остатака нису сачувани до данас. остаци.

Кључне речи: антички Naissus, положај града, истраживања, путописци, антички

Ниш је град који лежи на геотектонској граници кристаласте, родопске масе и кречњачких планина источне Србије и споју великих удолина Балканског полуострва, у котлини коју пресеца река Нишава. ${ }^{1}$ Сама нишка котлина је пространа и заузима површину од око $630 \mathrm{kм}^{2}$, али припада једној од најмањих котлина или области у јужноморавској регији. У котлини се данас налазе једно градско средиште,

\footnotetext{
${ }^{1}$ Историја Нима, I, Ниш 1983, 33.
} 
једно бањско лечилиште и око седамдесет и два сеоска насеља. ${ }^{2}$ Временом су се приградска насеља повезивала са градом, тако да се већ крајем 70-их година оцртава читава силуета града од изласка из Сићевачке клисуре па до Казнено-поправног дома, у укупној дужини од око осамнаест километара. ${ }^{3}$ Сам град Ниш смештен је на простору који заузима веома истакнут и значајан географски положај, међу долинама, планинама и важним саобраћајним пролазима и путевима који воде кроз средњи Балкан. У нишкој котлини се укршта шест важнијих саобраћајних праваца, од којих чак њих пет имају врло важну регионалну и међународну вредност. ${ }^{4}$ То су правци који воде долинама Мораве на север - према Београду, на југ - према Скопљу; долином Нишаве - према Софији; Тимока - према Влашком басену и Топлице - према Космету и Јадранском мору. ${ }^{5}$ Нишка котлина припада делу моравске котлине, те географски и културно припада средњебалканском региону, који уједно покрива и слив реке Мораве у целини. У овој се котлини такође укрштају две главне природне саобраћајнице, које су одиграле велику улогу у прошлости читавог овог краја, а нарочито старог Балкана, и то су: моравско-вардарска долина, која у ствари повезује источни Медитеран и обале Егејског мора са средњом Европом и Панонијом; други природни пут везује долину Нишаве и Поморавља са Топлицом и води према западу, преко Космета и Јадранског мора до Љеша и Драча. ${ }^{6}$ Поред овога, нишавска долина имала је одличну комуникацију и са софијским пољем и даље, преко Итхиманског превоја, са долином Марице, чиме је у ствари отворена друга природна комуникација према Медитерану и Блиском истоку. ${ }^{7}$ Зато се овде на овом простору, још више него на другим деловима Балкана, сусрећу и сучељавају разна културна струјања и стварају се услови за блиске међусобне контакте. То је у ствари и довело до стварања и формирања културних група праисторијског доба. ${ }^{8}$

Римљани и њихове војне трупе су на ове просторе дошли вероватно још у време Дарданског рата, који је трајао од 75. до 73. године пре н. е. Изгледа, међутим, да су се ови крајеви још дуго налазили ван оних области које су биле непосредно потчињене Римљанима. ${ }^{9}$ Податак о дефинитивном покоравању Дарданије до данас нам није познат, али се зна да су се сами Дарданци веома жестоко супротстављали дисциплинованим римским војницима. Римски војсковођа Гај Скрибоније Курион водио је јако насилан обрачун не само са непријатељима већ и са сопственом војском и то све у циљу застрашивања и подизања војничке дисциплине. ${ }^{10}$ Сам Курион је у овом походу стигао чак до Дунава али нам данас није познато какав је

\footnotetext{
${ }^{2}$ Исто.

${ }^{3}$ Исто, 34.

${ }^{4}$ Јован Ћирић, Географија општине Ниш, Нишки зборник, 12, Ниш 1983, 49.

${ }^{5}$ Исто.

${ }^{6}$ Енциклопедија Ниша - Историја, Ниш 1995, 235.

${ }^{7}$ Милутин Гарашанин, Праисторијске културе Поморавља и Источне Србије, каталог изложбе, Ниш $1973,11$.

${ }^{8}$ Исто, 12.

${ }^{9}$ Историја Ниша, I, 61.

${ }^{10}$ Фанула Папазоглу, Средњебалканска племена у предримско доба, Сарајево 1969, 139.
} 
положај имала Дарданија после овог великог, трогодишњег рата. Ова прва почетна освајања Римљана и њихове окупације нису нам, као што је наглашено, у довољној мери познати. Први значајни и поуздани подаци везани за догађаје на овим просторима датирају тек из I века нове ере, када је дефинитивно и читава територија данашње Србије укључена у састав велике римске државе. ${ }^{11}$ Ови простори тада нису представљали територију једног народа већ је то био мултиетнички простор на коме су, поред Дарданаца, живели и други народи и племена - Трачани и Келти. Ови народи су били у сталним међусобним ратовима и сукобима тако да ниједан од њих није успео да створи јаку и стабилну државу. Записи античких писаца о Келтима су за прошлост Ниша врло значајни, јер се у научном свету дуго мислило да су оснивачи Ниша у ствари били Келти. Међутим, њихов пролазак кроз Дарданију није оставио неке веће трагове на шта нам указују и врло ретки археолошки налази који се везују за келтски латен. ${ }^{12}$ Управо из овог периода I века н. е., потичу и први поуздани подаци да се у Наисусу (Naissus) већ налазе сталне војне посаде и веће римске јединице а потврду о томе имамо на натписима старих надгробних споменика. Прве војне јединице које се спомињу биле су I кохорта Килићана ${ }^{13}$ и I кохорта Крећана. ${ }^{14}$ Ово је период када се Наисус већ нашао у римској провинцији Мезији која је вероватно била формирана око 15. године, у време почетка Тиберијеве владавине (14-37. год. н. е.). ${ }^{15}$

Римски Наисус је заузимао централно место у новоформираној провинцији. Лежао је на раскрсници путева Балкана у то време, добијајући могућност најповољнијег повезивања како са Оријентом тако и са Подунављем, Јадранским и Јонским морем. Град је представљао центар од кога су се рачвали путеви: према југу ка Улпијани (Ulpiana) и Лисусу (Lissus), односно Скупију (Scupi); према северу у правцу према Виминацијуму (Viminacium) и Сингидунуму (Singidunum); према североистоку правцем Тимакум (Timacum) - Ратијарија (Ratiaria) и према истоку Сердика (Serdica) - Константинополис (Constantinopolis). ${ }^{16}$ У касној антици Наисус је припадао римској провинцији Дакија Медитеранеа (Dacia Mediterranea), a Прокопије ће га обележити као један од центара ове области. ${ }^{17}$ Међутим, прецизније податке о положају града имамо код античког писца Амијана Маркелина, који у једном свом извештају говори о Наисусу као граду у чијој се близини налази Медијана и која је од града удаљена око три миље, ${ }^{18}$ што нас у сваком случају, старим античким путем, доводи до великог Габровачког поља на коме се данас и налази савремени Ниш. ${ }^{19}$ Поред овога, податке о положају града имамо и код Приска који говори о положају Наисуса на пет дана хода од Дунава што је потпуно тачна

${ }^{11}$ Историја српског народа, књ. І, Београд 1994, 66.

12 Петар Петровић, Ниш у античко доба, Ниш 1976, 29.

${ }^{13}$ Енциклопедија Ниша, 166.

${ }^{14}$ Петар Петровић, Палеографија римских натписа у Горњој Мезији, Београд 1975, 132.

${ }^{15}$ П. Петровић, Ниш у античко доба, 30.

${ }^{16}$ Историја Ниша, I, 60.

${ }^{17}$ Исто,

${ }^{18}$ Амијан Марцелин Историја, превод Милена Милин, Београд 1987, 370

${ }^{19}$ П. Петровић, Ниш у античко доба, 24. 
констатација, јер стварно одговара растојању Ниша и Дунава. ${ }^{20}$ Приск говори и о томе да Наисус лежи на реци Дануба (Danuba), што би био још један помен античког назива Нишаве, али спомиње и хунску опсаду Наисуса из 441. године. ${ }^{21}$ Узевши све наведене податке у обзир, може се рећи да је стари Наисус смештен на десној обали реке, тј. око средишта велике котлине, на простору где се и данас налази савремени Ниш. Археолошка истраживања су само потврдила ове значајне податке. Данас нема сумњи да је град подигнут на врло стабилном терену, на обали реке, где је са сигурношћу био обезбеђен прелаз. Дуж цеста које су излазиле из града дошло је до развитка некропола - гробаља античких становника Наисуса. ${ }^{22}$ Наисус се, по површини коју је заузимао град од око двадесет и пет хектара, приближио већим античким градовима на Балкану. Има индиција да су се поједини делови града развијали и на левој обали реке - мала предграђа и некрополе, док су се виле и већа пољопривредна имања налазили на околним брдима. Ову констатацију у потпуности потврђују археолошка ископавања.

У дугом периоду под турском влашћу Ниш су често посећивали разни путници који су своја запажања бележили у путописима, извештајима, писмима или својим личним бележницама. Ови њихови подаци су данас од великог значаја као историјска грађа, у првом реду за реконструкцију градског изгледа али и за привредни и друштвени живот у оквиру турског царства. ${ }^{23}$ Они су описивали народ, начин живота, обичаје, веру, услове живљења, али и економски положај поробљеног народа. Немали број ових путописаца описао је чак и начин одевања нашег становништва у том периоду, што је такође врло значајан податак нарочито за етнологију средњег века. ${ }^{24}$ Међутим, за наш рад је првенствено значајно то што су поједини путописци средњег века и почетка новог века оставили врло значајне податке који су везани за античке остатке Наисуса. Они најчешће описују оно што су видели или чули о античкој прошлости града али је то врло значајан податак нарочито ако се узме у обзир то да је већина тих тадашњих остатака у каснијим периодима уништена и порушена. О многим споменицима Наисуса и њиховом постојању данас знамо само на основу тих записа, јер других података нема. На основу њих је могуће чак реконструисати неки објекат, па зато за овим записима научници редовно посежу. Први путописац који је оставио податке о античким рушевинама града био је Мартин Сегона, који је кроз Ниш прошао 1481. године и који говори о „Славној прошлости овог античког града који је данас у рушевинама““. ${ }^{25}$ Већ 1550. године кроз Ниш је прошао млетачки трговац Катарин

\footnotetext{
${ }^{20}$ Исто.

${ }^{21}$ Prisc. frg. 1b, p. 278, 22-280, 2;

${ }^{21}$ Prisc. frg. 8, p. $291,9-15$;

${ }^{22}$ Историја Ниша, I, 60.

${ }^{23}$ Исто, 174.

${ }^{24}$ Небојша Раденковић, Антички Naissus у српској науци, магистарски рад одбрањен на Филозофском факултету у Косовској Митровици 11. IV 2005, пред комисијом коју су чинили: ментор проф. др Момир Јовић, професор Универзитета у Приштини, проф. др Ксенија Марицки Гађански, професор Универзитета у Новом Саду, и проф. др Растко Васић, професор Универзитета у Косовској Митровици, 37.

${ }^{25}$ Исто, 175.
} 
Зен, који је оставио најлепши опис Топлице и предела око Ниша, али је у свом запису оставио податке и о старом, античком мосту преко Нишаве чији су се остаци у његово време још добро видели. ${ }^{26}$ У 1553 . години кроз Ниш је прошао и Антун Вранчић, школовани Шибенчанин, који је у име Хабзбуршке монархије преговарао са Турцима. ${ }^{27}$ У свом опису Ниша Вранчић прво говори о великом броју споменика са римским натписима, који су разбацани на све стране. ${ }^{28}$ Даље описује градске куће, од којих готово свака у свом зиду има понеки римски камен, а описује и темеље старих римских зидина које су порушене. ${ }^{29}$ Да је Вранчић био врло образован видимо из податка да спомиње и старо име града, по запису Птоломеја Несум (Nessum). ${ }^{30}$

Године 1555. мисији Антуна Вранчића придружио се и фламански хуманиста Ожер Гислен де Бузбек, који је био у служби шпанског краља Карла V. Он је такође записао своје утиске о Нишу, с тим да је први који је споменуо трагове старог римског пута али и једног малог мермерног стуба, чији су остаци били прилично оштећени па није могао да прочита латински натпис на њему. ${ }^{31}$ Ово указује на то да је у то време вероватно неки миљоказ, још из римског периода, био на свом месту. Путописци који су у другој половини XVI века пролазили кроз Ниш приметили су да је град почео да се повећава, изграђује и мења свој лик. ${ }^{32}$ Године 1567. Марк Антоније Пигафета, италијански дипломата, говори о остацима римске тврђаве који се још виде на самој обали Нишаве, али спомиње и Птоломејев попис римских градова на овом простору. ${ }^{33}$

Холанђанин Карло Рим писао је да је у време боравка у Нишу видео знатне остатке из римског периода, али описује и своје узбуђење пошто је у време његовог боравка у Нишу откривена нека подземна одаја у којој су била пронађена три римска саркофага. Те 1570. године Рим је био на пропутовању за Цариград и, како сам каже, „, Нишу је тада дошло до пуног трговачког успона. “34

Међу путописцима који су прошли кроз Ниш у овом периоду био је и путописац и протестантски свештеник Соломон Швајгер, који је у граду боравио 7. и 8. децембра $1577 .^{35} \mathrm{y}$ свом запису говори о старом натпису на мермерној плочи, коју је пронашао у близини зграде у којој је био смештен. Запис је пажљиво исписао a описао је и остатке појединих римских споменика, које, нажалост, није ишчитавао. ${ }^{36}$ Највећа вредност овог путописа је била у томе што је Швајгер урадио преко 100 илустрација у дрворезу и он свакако представља најбоље илустровани

\footnotetext{
${ }^{26}$ Историја Нииа, I, 178.

${ }^{27}$ Борислав Андрејевић, Стари записи о Нишу, Ниш 1997, 61.

${ }^{28}$ Исто.

${ }^{29}$ Исто.

${ }^{30}$ Исто, 63.

${ }_{31}^{31}$ Видосав Петровић, Нии у делима путописаиа, $I V-X X$ век, Ниш 2001, 89.

${ }^{32}$ Историја Ниша I, 187.

${ }^{33}$ Б. Андрејевић, Стари записи о Нишу, 72.

${ }^{34}$ Исто, 74.

${ }^{35}$ Исто, 95.

${ }^{36}$ Исто.
} 
путопис овог периода. То је и један од главних разлога за велику Швајгерову популарности у Немачкој где је његово дело од 1609. до 1664. године доживело пет издања. ${ }^{37}$

У јесен 1591. године прошао је кроз Ниш и свакако најмлађи путописац који је икада пропутовао кроз наше крајеве а који је и записао неке мање податке о античким остацима. Био је то петнаестогодишњи чешки племић Вратислав из Митровице, кога је познати аустријски посланик Фредерик Креквиц повео у своју пратњу ка Цариграду као свог пажа. ${ }^{38}$ Вратислав је, поред описа града и несреће која им се догодила дављењем у Нишави њиховог коњушара, описао и остатке римског пута који су још били видљиви на обали реке као и мермерни стуб са латинским натписом који је био у толикој мери оштећен да га сам путописац није могао прочитати. Иначе, Вратислављев путопис настао је дословно се држећи путописних белешки Ожера Бузбека који је знатно раније прошао и описао Ниш, што и није изненађујуће кад се узме у обзир првенствено Вратислављеве године и младост. ${ }^{39}$

Вести о римским старинама на простору града Ниша али и читаве Србије имамо и у великом броју других путописа из XVII и XVIII века, из времена када су вођени велики аустријско-турски ратови. У овим ратовима учествовао је и велики војни стратег и антиквар Еуген Савојски, љубитељ старина, у чијем поседу је сачуван и један од значајнијих извора античке географије, Tabula Peutingeriana, и који је својом делатношћу инспирисао своје сународнике који су нам оставили огроман број драгоцених белешки о старинама у Србији. ${ }^{40}$ Хуго од Вирмонта и Корнифиц Улфелд урадили су почетком XVIII века описе и цртеже плоча са рељефом из Ниша и Беле Паланке, а крајем XVII и почетком XVIII века настао је и велики број ратних планова и гравира свих већих градова тадашње Србије, Ужица, Ниша, Београда, Прокупља, Смедерева и других. На овим плановима налазе се и подаци о античкој топографији, путевима, старим објектима, војним утврђењима, о старим гробљима, објектима за водоснабдевање и слично, али ови документи до данас нису детаљније анализирани са становиштва археологије, што би значајно допринело плановима и правцима даљих истраживања. ${ }^{41}$ Што се тиче периода XIX века, несумњиво је највећи значај имала делатност познатог путописца Феликса Каница који је вероватно први истраживач који ће на научним основама пописати све римске старине у Нишу и читавој Србији, а његова прва археолошка истраживања на великом броју локалитета с правом му дају назив оснивача античке археологије наших простора. ${ }^{42}$

Из наведених података путописаца можемо закључити да је у њихово време

\footnotetext{
${ }^{37}$ Историја Ниша, I, 186.

${ }^{38}$ Исто, 188.

${ }^{39}$ Исто.

${ }^{40}$ Петар Петровић, Европски научници и почеци античке археологије код Срба, Античке студије код Срба, Зборник радова са научног скупа одржаног 3-4. јуна 1987. године у Београду и Новом Саду, Београд $1896,260$.

${ }^{41}$ Исто.

${ }^{42}$ Небојша Раденковић, Феликс Кании и антички Нии, Зборник радова са међународног научног скупа Антички свет, европска и српска наука (ур. Ксенија Марицки Гађански), Београд 2009, 288.
} 
у Нишу био још прилично добро очуван већи број римских споменика. Описи тих споменика првенствено зависе од нивоа интересовања тих путописаца за старине, али и од степена њиховог образовања. Међутим, они свакако представљају врло драгоцен историографски материјал како за средњовековну прошлост тако и за античку прошлост, не само града Ниша већ и читаве Србије, па их у одређеној мери истраживачи и данас користе.

\section{Литература:}

Андрејевић, Борислав, Стари записи о Нишу, Ниш 1997.

Гарашанин, Милутин, Праисторијске културе Поморавља и Источне Србије, Каталог изложбе, Ниш 1973.

Енциклопедија Ниша - Историја, Ниш 1995.

Историја Ниша, том 1, Ниш 1983.

Историја српског народа, књ. І, Београд 1994.

Марцелин, Амијан, Историја, превод Милена Милин, Београд 1987.

Папазоглу, Фанула, Средњебалканска племена у предримско доба, Сарајево 1969.

Петровић, Видосав, Ниш у делима путописаиа, IV-XX век, Ниш 2001.

Петровић, Петар, Европски научници и почеци античке археологије код Срба. Античке студије код Срба, Зборник радова са научног скупа одржаног 3-4. јуна 1987. године у Београду и Новом Саду, Београд 1986, 257-267.

Петровић, Петар, Нии у античко доба, Ниш 1976.

Петровић, Петар, Палеографија римских натписа у Горњој Мезији, Београд 1975.

Prisc. frg. 1 b, p. 278, 22-280, 2; Prisc. frg. 8, p. 291, 9-15; Византијски извори за историју народа Југославије, том 1, CAH, посебна издања, књига CCXLI, Византолошки институт, књ. 3, Београд 1955.

Раденковић, Небојша, Антички Naissus y српској науции, магистарски рад одбрањен на Филозофском факултету у Косовској Митровици 11. IV 2005. године, пред комисијом коју су чинили: ментор проф. др Момир Јовић, професор Универзитета у Приштини, проф. др Ксенија Марицки Гађански, професор Универзитета у Новом Саду, и проф. др Растко Васић, професор Универзитета у Косовској Митровици.

Раденковић, Небојша, Феликс Кании и антички Нии, Зборник радова са међународног научног скупа „Антички свет, европска и српска наука“ (ур. Ксенија Марицки Гађански), Београд 2009, 284-294.

Ћирић, Јован, Географија општине Ниш, Нишки зборник, 12, Ниш 1983. 


\title{
TRACES OF ANCIENT NAISSUS IN THE WORKS OF TRAVELLERS OF THE $16^{\text {th }}$ CENTURY
}

\begin{abstract}
Summary
In this paper the author presents, in brief, both ancient past of Naissus and ancient remains of this significant city in the 16th and 17th centuries. A great number of travellers passing through this city described it in their writings. Many of them travelling as western envoys towards Constantinople noticed and described our people, customs, national costumes, but also the remains from the antiquity to the Turkish sultan. These records had great significance for later research of our scientists.
\end{abstract} remains.

Keywords: ancient Naissus, town position, exploration, travellers, ancient 